\title{
Cutting out the middle clam: lucinid endosymbiotic bacteria are also associated with seagrass roots worldwide
}

\author{
Belinda C. Martin $\mathbb{D}^{1,2,3} \cdot$ Jen A. Middleton ${ }^{2,3} \cdot{\text { Matthew W. Fraser } \mathbb{D}^{1,2} \cdot \operatorname{lan} \text { P. G. Marshall }}^{4} \cdot$ Vincent V. Scholz $^{4} \cdot$ \\ Bertram Hausl $^{5} \cdot$ Hannes Schmidt ${ }^{6}$
}

Received: 3 May 2020 / Revised: 18 August 2020 / Accepted: 2 September 2020 / Published online: 14 September 2020

(c) International Society for Microbial Ecology 2020

\begin{abstract}
Seagrasses and lucinid bivalves inhabit highly reduced sediments with elevated sulphide concentrations. Lucinids house symbiotic bacteria ( $\mathrm{Ca}$. Thiodiazotropha) capable of oxidising sediment sulphide, and their presence in sediments has been proposed to promote seagrass growth by decreasing otherwise phytotoxic sulphide levels. However, vast and productive seagrass meadows are present in ecosystems where lucinids do not occur. Hence, we hypothesised that seagrasses themselves host these sulphur-oxidising $\mathrm{Ca}$. Thiodiazotropha that could aid their survival when lucinids are absent. We analysed newly generated and publicly available 16S rRNA gene sequences from seagrass roots and sediments across 14 seagrass species and 10 countries and found that persistent and colonising seagrasses across the world harbour sulphuroxidising $\mathrm{Ca}$. Thiodiazotropha, regardless of the presence of lucinids. We used fluorescence in situ hybridisation to visually confirm the presence of $\mathrm{Ca}$. Thiodiazotropha on roots of Halophila ovalis, a colonising seagrass species with wide geographical, water depth range, and sedimentary sulphide concentrations. We provide the first evidence that $\mathrm{Ca}$. Thiodiazotropha are commonly present on seagrass roots, providing another mechanism for seagrasses to alleviate sulphide stress globally.
\end{abstract}

\section{Introduction}

Seagrasses are marine flowering plants that cover an estimated global area of $300,000-600,000 \mathrm{~km}^{2}$ and are crucial

Supplementary information The online version of this article (https:// doi.org/10.1038/s41396-020-00771-3) contains supplementary material, which is available to authorized users.

Belinda C. Martin

Belinda.martin@uwa.edu.au

1 UWA Oceans Institute, The University of Western Australia, 35 Stirling Highway, Crawley, WA 6009, Australia

2 School of Biological Sciences, The University of Western Australia, 35 Stirling Highway, Crawley, WA 6009, Australia

3 Ooid Scientific, White Gum Valley, WA 6162, Australia

4 Center for Electromicrobiology, Aarhus University, Ny Munkegade 116, DK-8000 Aarhus C, Denmark

5 Department of Microbiology and Ecosystem Science, University of Vienna, Vienna 1090, Austria

6 Department of Microbiology and Ecosystem Science, University of Vienna, Vienna 1090, Austria to the health of shallow coastal ecosystems worldwide [1]. Seagrasses typically thrive in highly reduced sediments where sulphide concentrations can accumulate to phytotoxic levels (>10 $\mathrm{mol} \mathrm{L}^{-1}$ [2]), which presents an ongoing enigma as to how they survive. Several hypotheses have been presented, including oxidation of sulphides internally in the aerenchyma and externally in the rhizosphere by radial oxygen loss and by root associated sulphide oxidising bacteria [3-5]. Bivalves belonging to the family Lucinidae have also been proposed as a mechanism for sulphide detoxification in seagrass beds globally [6]. Lucinids, unlike most animals, thrive in sulphide-rich sediments as they house symbiotic chemoautotrophic bacteria ( $\mathrm{Ca}$. Thiodiazotropha) inside their gills which oxidise sulphides to provide energy for $\mathrm{CO}_{2}$ fixation. In this tripartite relationship, seagrasses benefit from minimised sulphide intrusion, whilst lucinids and their symbionts profit from enhanced sulphide production arising from seagrass organic matter accumulation, which fuels microbial sulphate reduction [3]. This relationship has been recently tested in the field, where increased densities of the lucinid Loripes orbiculatus correlated with reduced sulphide intrusion in the seagrass Zostera noltei [7]. Whilst this study provides compelling 
evidence for sulphide detoxification for seagrass systems with high densities of lucinid bivalves, it is not adequate for explaining sulphide detoxification for systems lacking lucinids.

Lucinids acquire their endosymbionts in free-living stage from the environment, believed to be a result of chance encounters with potential symbionts during the juvenile phase $[8,9]$. It follows that seagrass roots, which provide a chemical environment that bears a striking resemblance to lucinid gills (i.e., gradients of oxygen, organic matter, sulphide and carbon dioxide availability) $[10,11]$, would also provide a suitable niche to attract and possibly attain these bacteria. As part of recolonisation of the marine environment, seagrasses require adaptions to cope with high sulphide environments, one of which could be supported via their root microbiota. Thus, we hypothesized that seagrass roots harbour sulphuroxidising $\mathrm{Ca}$. Thiodiazotropha, which could explain their successful colonisation even in sulphide-rich sediments where lucinids are absent.

\section{Methods}

To explore the possibility that seagrass roots serve as a suitable habitat for $C a$. Thiodiazotropha, we analysed $16 \mathrm{~S}$ rRNA gene sequences (Illumina MiSeq platform) recovered from publicly available and newly generated data on seagrass roots and sediments across 14 seagrass species and 10 countries (Fig. S1; Supplementary methods, Table S1 and Table S2; Supplementary datasets). All raw sequences were processed through the DADA2 pipeline [12] using SILVA 132 database [13] to assign taxonomy ( $\mathrm{R}$ markdown file in Supplementary). Amplicon Sequence Variants (ASVs) classified as $\mathrm{Ca}$. Thiodiazotropha were compared to SILVA 138 using blastn (v 2.2.29+) [13] and a phylogenetic tree was constructed using PhyML [14] with 1000 bootstraps. We also applied fluorescence in situ hybridisation (FISH) to visualise $\mathrm{Ca}$. Thiodiazotropha on roots of the seagrass Halophila ovalis following the protocol outlined in [11] (detailed methods in Supplementary, Table S3 and Table S4, and Fig. S2 and Fig. S3).

\section{Results and discussion}

We recovered $\mathrm{Ca}$. Thiodiazotropha sequences from roots of 12 of the 14 seagrass species analysed, comprising four seagrass families and three independent lineages of seagrass evolution [15]. When present, $C a$. Thiodiazotropha sequences were consistently more abundant in seagrass root samples compared to the surrounding sediment, where often no sequences were recovered at all (Fig. 1b). $\mathrm{Ca}$. Thiodiazotropha sequences were also found in seagrasses of all functional types; from large, slow growing seagrass species that develop persistent meadows such as Posidonia spp. to smaller fast growing species that form transient meadows such as Halophila spp. (Fig. 1). Data are skewed towards temperate systems, however, $\mathrm{Ca}$. Thiodiazotropha sequences were also obtained from tropical seagrass roots in Florida, as well as the tropical Paracel Islands in the South China Sea (Fig. S1 and interactive map; Supplementary material). Notably, comparable levels of relative abundance of $\mathrm{Ca}$. Thiodiazotropha from seagrass roots appeared independent of the presence or absence of lucinids (Fig. 1c). Together, this suggests that $\mathrm{Ca}$. Thiodiazotropha colonise seagrasses irrespective of their geography, lifestyle, evolutionary history and proximity to lucinids likely because the root environment and its mosaic of chemical gradients (e.g. oxygen, $\mathrm{pH}$, metals and nutrients) $[10,11]$ provides a suitable niche for these chemoautotrophs.

Most seagrass species exhibited a relatively diverse set of ASVs aligning to known endosymbionts of lucinid species (Fig. S4; Supplementary). Some lucinid species also exhibit diversity in their endosymbionts, possibly as a reflection of the diversity of free-living symbionts present in the environment [8, 9]. To date, functional analysis of three gill edosymbionts (including $\mathrm{Ca}$. Thiodiazotropha endolucinida indicated in Fig. S2), revealed not only genes relating to chemoautotrophy, but also diazotrophy, heterotrophy and oxidation of $\mathrm{C} 1$ compounds [8, 16-18]. Hence these bacteria may not only provide a means for lowering sediment sulphide levels, but may also provide an additional source of $\mathrm{NH}_{4}{ }^{+}$via nitrogen fixation; the preferred source of $\mathrm{N}$ for seagrass uptake [19].

FISH with a $\mathrm{Ca}$. Thiodiazotropha-targeted oligonucleotide probe combined with class- and domain-level probes showed that $\mathrm{Ca}$. Thiodiazotropha forms dense colonies on the surface of Halophila ovalis roots, particularly in axial grooves between epidermal cells and on the base of root hairs (Fig. 2, Fig. S5; Supplementary). Strikingly, a morphological diversity of $\mathrm{Ca}$. Thiodiazotropha was apparent in FISH images-with smaller single-cell rods $(\sim 1 \mu \mathrm{m})$ present on the root surface (e.g. Fig. S5a; Supplementary), as well as larger coccoid shaped $(\sim 2 \mu \mathrm{m})$ cells (e.g. Fig. S5d; Supplementary) that form dense colonies in axial grooves and root hairs. Such differences in morphology have been previously observed between extracellular (those found in the sediment) and intracellular lifestyles (those located inside lucinid gills) for the symbionts of the lucinid Codakia orbicularis [20]. We cannot say if our observations of 


\section{Persistent \\ a}
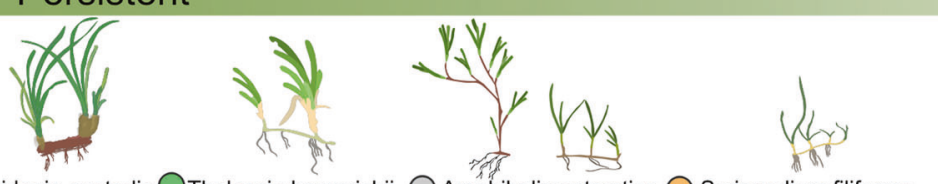

Syringodium filiforme

Syringodium isoetifolium $\bigcirc$ Zostera muelleri

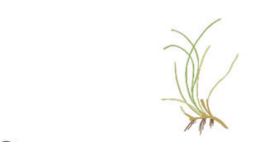

Colonising
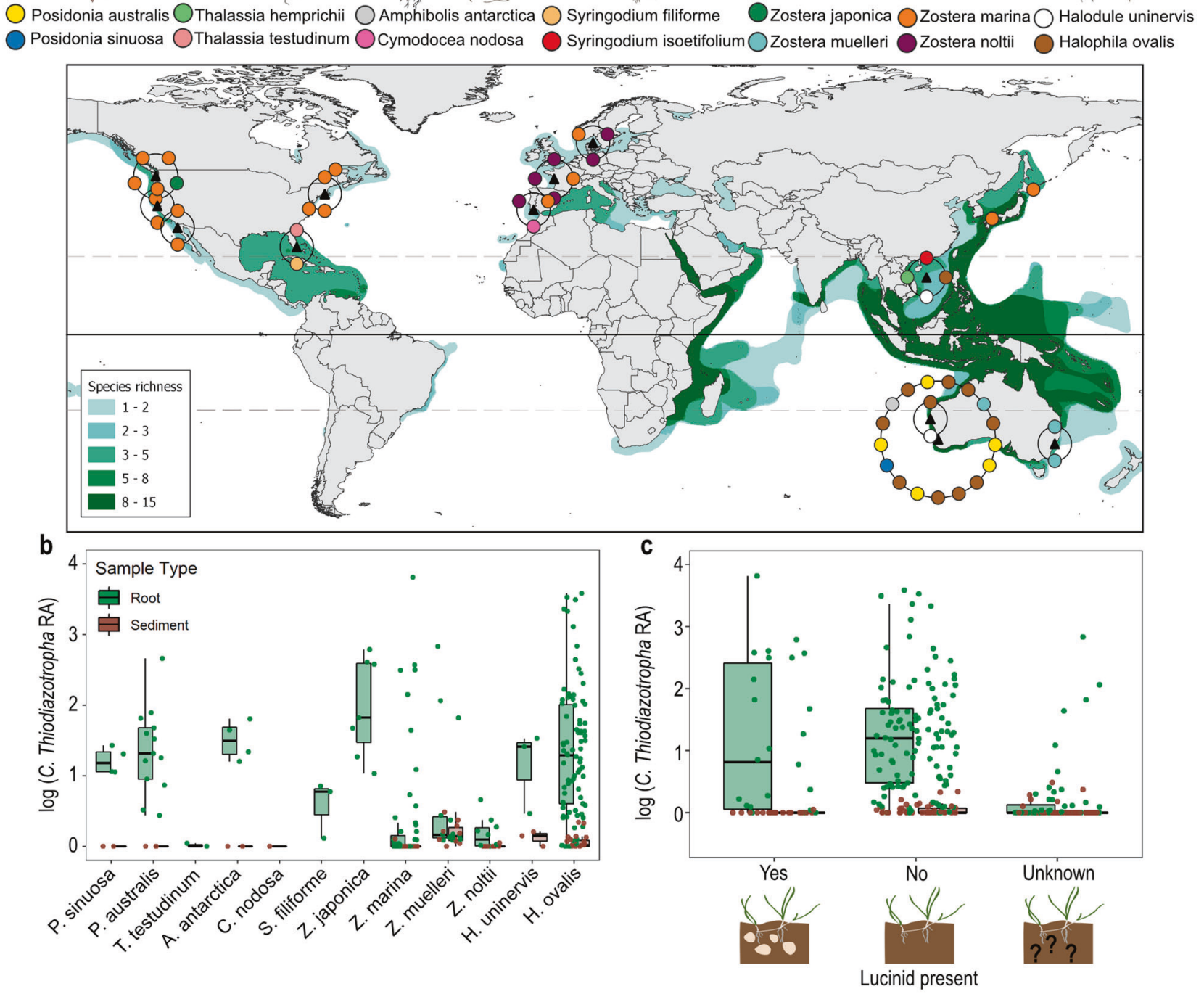

Fig. 1 Global distribution of seagrass samples and the relative abundance of $\boldsymbol{C a}$. Thiodiazotropha. a Seagrass species and sample locations analysed in this study and the global distribution of seagrass species. Seagrasses are classified by functional type; with seagrasses on the left classified as persistent (large, slow growing persistent meadows), and those on the right as colonising (small, fast growing transient meadows). Global seagrass distribution data was acquired from Green EP and Short FT, World atlas of seagrasses. 2003. Black triangles indicate a cluster of sites and/or seagrass species that were

collected in close proximity. Location meta-data can be found in Table S1 and Table S2, as well as collection details and primer information. b Relative abundance of $\mathrm{Ca}$. Thiodiazotropha sequences (natural log scale +1 ) recovered from all seagrass roots and sediments. c Relative abundance of $\mathrm{Ca}$. Thiodiazotropha sequences ()(natural log scale +1 ) recovered from seagrass roots and sediments from environments with and without lucinids present (lucinid presense/absence references available in Table S2).

$\mathrm{Ca}$. Thiodiazotropha is a reflection of morphological plasticity or closely related strains with differing morphologies. Regardless, we provide the first in situ evidence that $\mathrm{Ca}$. Thiodiazotropha is colonising seagrass roots in high abundances. Together with amplicon sequencing based evidence that $\mathrm{Ca}$. Thiodiazotropha are associated with seagrasses of varying life-strategies and evolutionary histories worldwide, our data suggests that this relationship may be both general and another essential mechanism for seagrasses to thrive in sulphiderich sediments, thus extending the proposed lucinidseagrass relationship. 
Fig. 2 Projected images of Halophila ovalis roots (collected from the Swan River, Western Australia, Australia) with associated populations of $\mathrm{Ca}$.

Thiodiazotropha. a overlay of all probes. Large clusters of $\mathrm{Ca}$. Thiodiazotropha can be seen in yellow/white (white arrow heads) and populations of other bacteria (particularly

filamentous bacteria) can be seen in red. Several root hairs are present (rh; white arrow) and the epidermal cells of the seagrass are also visible (ec; white arrow). N.B. H. ovalis possesses no lateral roots, so all 'branching' are root hairs (i.e., not lateral roots). b Bacteria (probe: EUBI-III-ATTO 647), c Gammaproteobacteria (probe: GAM42a-ATTO 565), d $\mathrm{Ca}$.

Thiodiazotropha (probe: THIO847) e transmission image with the bases of root hairs (rh) indiacted with black arrows. Scale bars: $10 \mu \mathrm{m}$.
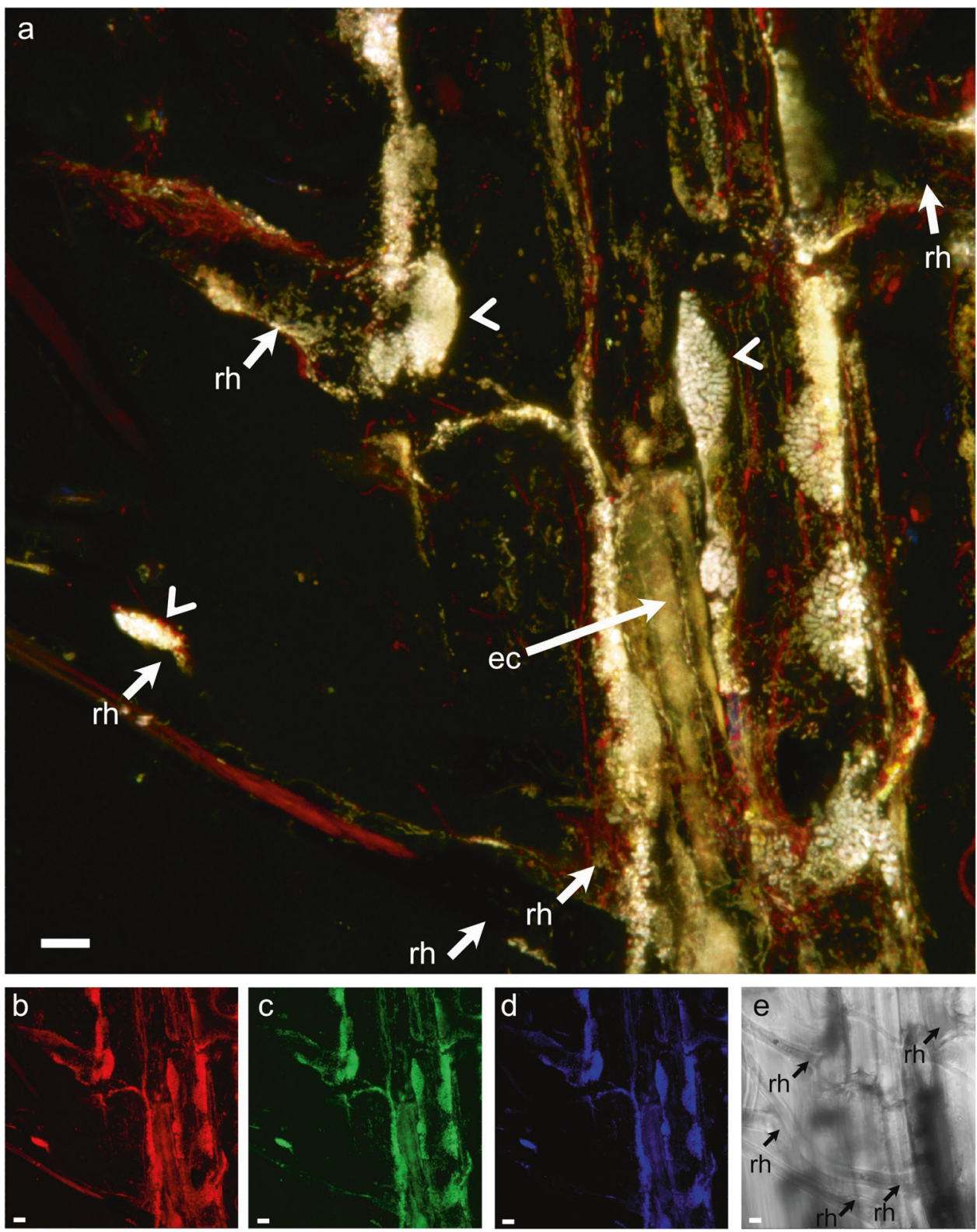

Acknowledgements We wish to thank Gary Kendrick, Jeremy Bougoure, Daniela Trojan, PWIS and PP for advice and fruitful discussions. MWF was supported by the Robson and Robertson postdoctoral fellowship awarded by the UWA Oceans Institute. This research was partly supported by the Integrated Coastal Analyses and Sensor Technology (ICoAST) project with funding from the Indian Ocean Marine Research Centre, a joint partnership between The University of Western Australia (UWA), the Australian Institute of Marine Science (AIMS), The Commonwealth Scientific and Industrial Research Organisation (CSIRO) and The Department of Primary Industries and Regional Development (DPIRD) WA. We also acknowledge the facilities, and the scientific and technical assistance of Microscopy Australia at the Centre for Microscopy, Characterisation \& Analysis, The University of Western Australia, a facility funded by the University, State and Commonwealth Governments.

\section{Compliance with ethical standards}

Conflict of interest The authors declare that they have no conflict of interest.

Publisher's note Springer Nature remains neutral with regard to jurisdictional claims in published maps and institutional affiliations.

\section{References}

1. Orth RJ, Carruthers TJB, Dennison WC, Duarte CM, Fourqurean JW, Heck KL, et al. A global crisis for seagrass ecosystems. Bioscience. 2006;56:987-96.

2. Lamers LPM, Govers LL, Janssen ICJM, Geurts JJM, Van der Welle MEW, Van Katwijk MM, et al. Sulfide as a soil phytotoxina review. Front Plant Sci. 2013;4:268. 
3. Hasler-Sheetal H, Holmer M. Sulfide intrusion and detoxification in the seagrass Zostera marina. PLoS One. 2015;10:1-19.

4. Brodersen KE, Lichtenberg M, Paz LC, Kühl M Epiphyte-cover on seagrass (Zostera marina L.) leaves impedes plant performance and radial $\mathrm{O} 2$ loss from the below-ground tissue. Front Mar Sci. 2015;2:1-11.

5. Fahimipour AK, Kardish MR, Lang JM, Green JL, Eisen JA, Stachowicz JJ. Global-scale structure of the eelgrass microbiome. Appl Environ Microbiol. 2017;83:1-12.

6. Van der Heide T, Govers LL, de Fouw J, Olff H, Van der Geest M, Van Katwijk MM, et al. A three-stage symbiosis forms the foundation of seagrass ecosystems. Science. 2012;336:1432-4.

7. Van Der Geest M, Van Der Heide T, Holmer M, De Wit R. First field-based evidence that the seagrass-lucinid mutualism can mitigate sulfide stress in seagrasses. Front Mar Sci. 2020;7:1-13.

8. Lim SJ, Alexander L, Engel AS, Paterson AT, Anderson LC, Campbell BJ. Extensive thioautotrophic gill endosymbiont diversity within a single Ctena orbiculata (Bivalvia: Lucinidae) population and implications for defining host-symbiont specificity and species recognition. mSystems. 2019;4:1-19.

9. Brissac T, Merçot H, Gros O. Lucinidae/sulfur-oxidizing bacteria: ancestral heritage or opportunistic association? Further insights from the Bohol Sea (the Philippines). FEMS Microbiol Ecol. 2011;75:63-76.

10. Brodersen KE, Koren K, Moßhammer M, Ralph PJ, Kühl M, Santner J. Seagrass-mediated phosphorus and iron solubilization in tropical sediments. Environ Sci Technol. 2017;51:14155-63.

11. Martin BC, Bougoure J, Ryan MH, Bennett WW, Colmer TD, Joyce NK, et al. Oxygen loss from seagrass roots coincides with colonisation of sulphide-oxidising cable bacteria and reduces sulphide stress. ISME J. 2019;13:707-19.
12. Callahan BJ, McMurdie PJ, Rosen M, Han AW, Johnson AJA, Holmes S. DADA2: High resolution sample inference from Illumina amplicon data. Nat Methods. 2016;13:4-5.

13. Quast C, Pruesse E, Yilmaz P, Gerken J, Schweer T, Yarza P, et al. The SILVA ribosomal RNA gene database project: Improved data processing and web-based tools. Nucleic Acids Res. 2013;41:590-6.

14. Guindon S, Gascuel O. A simple, fast, and accurate algorithm to estimate large phylogenies by maximum likelihood. Syst Biol. 2003;52:696-704.

15. Les DH, Cleland MA, Waycott M. Phylogenetic studies in alismatidae, II: evolution of marine angiosperms (Seagrasses) and hydrophily. Am Soc Plant Taxon. 1997;22:443-63.

16. Petersen JM, Kemper A, Gruber-Vodicka H, Cardini U, Van Der Geest M, Kleiner M, et al. Chemosynthetic symbionts of marine invertebrate animals are capable of nitrogen fixation. Nat Microbiol. 2016;2:1-11.

17. König S, Gros O, Heiden SE, Hinzke T, Thürmer A, Poehlein A, et al. Nitrogen fixation in a chemoautotrophic lucinid symbiosis. Nat Microbiol. 2016;2:16193.

18. Lim SJ, Davis BG, Gill DE, Walton J, Nachman E, Engel AS, et al. Taxonomic and functional heterogeneity of the gill microbiome in a symbiotic coastal mangrove lucinid species. ISME J. 2019;13:902-20.

19. Touchette BW, Burkholder JM. Review of nitrogen and phosphorus metabolism in seagrasses. J Exp Bot. 2000;250: 133-67.

20. Gros O, Liberge M, Heddi A, Khatchadourian C, Felbeck H. Detection of the free-living forms of sulfide-oxidizing gill endosymbionts in the lucinid habitat (thalassia testudinum environment). Appl Environ Microbiol. 2003;69:6264-7. 